\title{
On the firing line - interactions between hunting frogs and Odonata
}

\author{
Georg Rüppella*, Dagmar Hilfert-Rüppell ${ }^{\mathrm{b}}$, Beat Schneider ${ }^{\mathrm{c}}$ and Hanna Dedenbach ${ }^{\mathrm{d}}$ \\ ${ }^{a}$ Independent Scholar, An der Wasserfurche 32, Cremlingen, Germany; ${ }^{b}$ Institute of Science Education, \\ Technical University of Braunschweig, Braunschweig, Germany; ${ }^{c}$ Independent Scholar, Wolfbühlstraße 34 \\ A, Winterthur, Switzerland; ${ }^{d}$ Independent Scholar, Gebrüder-Witte-Straße 20, Greifswald, Germany
}

\begin{abstract}
Frogs are important predators of Odonata. We investigated frogs catching Odonata prey by means of slow-motion filming in the field in order to understand the prey-predator interactions. In particular, we aimed to analyse kinematics of captures, and of Odonata fleeing, through evaluation of frame-by-frame filming; $122(20 \%)$ of 613 events were analysed. While dragonflies were ovipositing, frogs were sitting and waiting motionless, or they sneaked slowly towards the intended prey. The speed of the lashing tongue was much higher than the start and flight velocities of Odonata during escape attempts. The reaction time of Odonata was around $45 \times 10^{-3} \mathrm{~s}$, and it was not correlated to capture rate. The fleeing behaviour of Odonata cannot be considered to be stereotypical. The usual fleeing measure was to evade sideways to the jump direction of the frog, with the individual turning their body to one side and flying away from the frog. Perched odonates escaped by overturning to one side, sometimes falling into the water, or by flying in a loop. To escape, individuals were observed flying backward with the head down, in two cases. From the video clips, capture rates were counted. Large Anisoptera escaped more often than small Zygoptera. Anax imperator females mostly escaped after capture by fighting with strong wing beats, even when pulled under water by the frog.
\end{abstract}

Keywords: predation; dragonfly; oviposition; flight; acceleration; escape flight; capture rate; frog jump; frog tongue

\section{Introduction}

Frogs are specialized jumping hunters (Marsh \& John-Alder, 1994) equipped with a sticky flip tongue. The coloration of green frogs provides camouflage and the upward position of their eyes provides wide-angle vision; it has been shown that Anura have basic neuroanatomical adaptations which enhance the speed and accuracy of their stereoscopic vision, and frogs use retinal elevation as a cue to distance (Collett \& Udin, 1988). The relative body size affects the predatorprey relationship in that small frogs hunt small insects, and larger frogs hunt odonates (own observations; Günther, 1996). Hunting frogs have three options to attack their prey: with their tongue, their forelegs or with their body. When the tongue misses, the body can dump the prey to the water, where the forelegs can take over. In jumping, the outstretched forelegs enlarge the catching profile (Rüppell, 1984). The kinematics of the tongue is complex (Anderson, 1993; Nishikawa \& Roth, 1991). The tongue saliva is a shear-thinning fluid (Noel, Guo, Mandica, \&

*Corresponding author. Email: g.rueppell@ freenet.de 
$\mathrm{Hu}$, 2017). That means it is rapidly stretchable, but when hitting an object, it becomes more viscous and is able to adhere very tightly to the prey's surface (Kleinteich and Gorb, 2015). This means the tongue can be catapulted very fast and can then pull prey towards the mouth.

Odonata are among the best fliers in the animal kingdom. They are divided into two main groups: small and slender Zygoptera and large and broader Anisoptera. While Zygoptera show an outstanding manoeuvrability and acceleration, anisopteran flight is very fast and powerful (Rüppell, 1989). Besides transformation from water-living larvae to the flying adult, the most dangerous situations in a dragonfly's life occur during egg-laying. When ovipositing, all odonatan females have to approach the water's surface, where frogs are lurking. Odonata apply two modes of ovipositing: Zygoptera and evolutionarily older anisopteran species lay eggs endophytically while sitting, drilling a hole into a leaf and deposit an egg. This mode costs more time than laying eggs exophytically while flying, throwing eggs out while dipping (Conrad \& Pritchard, 1992). Frog attacks are expected to happen more often in Odonata species which lay eggs endophytically (Rehfeldt, 1995). Moreover, many Zygoptera species and some Anisoptera lay eggs in the tandem position, interpreted as an anti-predator and anti-male-competition posture (Rehfeldt, 1990; Corbet, 1999; Curley, Rowley, \& Speed, 2015). But this coupled position between males and females affects their flight performance: the tandem is less manoeuvrable (Rüppell, 1989).

Another method to decrease predation risk is to change the oviposition site frequently (Rehfeldt, 1990). But the most common and direct measure to escape is fleeing by flight. The aim of Odonata must be to get out of the reach of the frog quickly.

After analysing frogs' hunting behaviour (Rüppell, 1984), the following hypotheses are considered:

(1) To escape, Odonata need to exhibit extreme flight manoeuvres.

(2) Anisoptera are more powerful and faster fliers than Zygoptera, and thus should more often avoid frog predation.

(3) Endophytic oviposition should cause more losses than exophytic oviposition, because it takes more time to take off.

\section{Material and methods}

During the summers from 2009 to 2018, frogs were filmed in slow motion (250-600 $\mathrm{f} \mathrm{s}^{-1}$ ) when catching prey. The filming was done with digital cameras (Casio EX F1(Yamagata, Japan), Sony RX 10 III(Shenzen, China), Panasonic Lumix GH 5, GH 5s(Kadoma, Japan)). The two first cameras have a prerecord mode, which means that the camera get the action after it happened. Although mostly actions at an angle of about $90^{\circ}$ to the imaging line were analysed, due to the perspective distortion, deviations of about 5-10\% had to be accepted. The videos were analysed frame-by-frame using the editing program Magix Video Deluxe Plus (www.magix.com.de, Berlin, Germany) on an notebook computer. In order to obtain distance measurements, the full length of either a wing or the body of an individual of Odonata was taken as a mean value from the data of Dijkstra (2006). Time courses could be determined from the frequency of the video. All investigations were made in sunny weather at temperatures between 25 and $30^{\circ} \mathrm{C}$. The investigation sites were in Switzerland near Winterthur $\left(47^{\circ} 35^{\prime} \mathrm{N}, 8^{\circ} 52^{\prime} \mathrm{E}\right)$, and in northern Germany near Braunschweig at ponds $\left(52^{\circ} 15^{\prime} \mathrm{N}, 10^{\circ} 35^{\prime} \mathrm{E}\right)$, and at the river Oker $\left(52^{\circ} 26^{\prime} \mathrm{N}, 10^{\circ} 23^{\prime} \mathrm{E}\right)$, which was about $12-18 \mathrm{~m}$ wide, and $0.7-1.5 \mathrm{~m}$ deep in the main channel. Observed frogs (Pelophylax esculentus) ranged in size between 4 and $8 \mathrm{~cm}$ in body length (without outstretched legs). The seven investigated Odonata species differ in body dimensions. The data presented in Table 1, obtained from the literature, can only give a rough picture, because the available data, other than 
Table 1. Body dimensions and oviposition mode of the investigated species. Body length and wing length taken from Dijkstra (2006) and body mass taken from Grabow and Rüppell (2014). Those marked with an multiplication symbol are extrapolated values from related species of similar size.

\begin{tabular}{lcccl}
\hline Species & Body length $(\mathrm{mm})$ & Hind wing length $(\mathrm{mm})$ & Mass $(\mathrm{g})$ & Oviposition \\
\hline Calopteryx splendens & $45-48$ & $27-36$ & $120 / 156$ & Single, endophytic \\
Enallagma cyathigerum & $29-36$ & $15-21$ & $33 / 40 \times$ & Tandem, endophytic \\
Coenagrion puella & $33-35$ & $15-24$ & $34 / 50 \times$ & Tandem, endophytic \\
Aeshna cyanea & $67-76$ & $43-53$ & $729 / 1098$ & Single, endophytic \\
Anax imperator & $66-84$ & $45-52$ & $750 / 1200 \times$ & Single, endophytic \\
Libellula quadrimaculata & $40-48$ & $32-40$ & $382 / 350$ & Single, exophytic \\
Sympetrum striolatum & $35-44$ & $24-30$ & $130 / 160 \times$ & Tandem, exophytic \\
\hline
\end{tabular}

body mass, are not divided by sexes. One single film was made of an attack on Platycnemis pennipes in tandem. The ovipositions are categorized as endo- or exophytic, and as single or tandem, since these variables may influence the capture rate. In Enallagma cyathigerum, Coenagrion puella and Sympetrum striolatum the tandem mode is predominant, while single oviposition of females may occur occasionally.

The reaction times of the dragonflies and damselflies were measured from the first movement of the jumping frog to the first fleeing movement of the odonate. Only those videos were analysed in which reaction times could be determined exactly. This was easy when the odonates were sitting and oviposition was endophytic. Since some females and some tandem males moved their wings permanently during oviposition, the first outstanding sign of wing movement was recorded. These movements were sudden increased beat angles or changes in phase relationship or beat direction. In flying odonates these behaviours were sometimes distinct, as in flying Anax imperator, but in Sympetrum species that oviposit while flying in tandem, the exact timing could not always be recognized. So, Sympetrum was not included in this hypothesis.

\section{Results}

\section{Frog hunting behaviour}

The first step for the frogs was a promising jump distance. When hunting, frogs sat motionless but sometimes aligned their body and sneaked up or rarely dived very slowly. Jumping distances were always longer than prey distances. Jumping distances at hunts on Coenagrion puella tandems were $22.8 \mathrm{~cm}(\mathrm{SD} \pm 5.8, \mathrm{~N}=7)$ at prey distances of $12.9 \mathrm{~cm}(\mathrm{SD} \pm 3.5, \mathrm{~N}=7)$. The tongue was outstretched for a mean $101.4 \times 10^{-3} \mathrm{~s}\left(\mathrm{SD} \pm 27.3 \times 10^{-3}, \mathrm{~N}=28\right)$ after the jump began. Opening mouth and initial tongue projection took a mean $20.3 \times 10^{-3} \mathrm{~s}\left(\mathrm{SD} \pm 3.7 \times 10^{-3}\right.$, $\mathrm{N}=26$ ) before the outstretched phase. The mean maximal body speed in six jumps from the water was $1.46 \mathrm{~m} \mathrm{~s}^{-1}(\mathrm{SD} \pm 0.41)$, reaching $2.5 \mathrm{~m} \mathrm{~s}^{-1}$ in one case when jumping from a hard gravel bank a little downward. The speed of the tongue (over ground) was mean $5.03 \mathrm{~m} \mathrm{~s}^{-1}$ $(\mathrm{N}=11, \mathrm{SD} \pm 0.64)$. That was much faster than the flight speed of the fleeing Odonata with mean $1.17 \mathrm{~m} \mathrm{~s}^{-1}(\mathrm{~N}=14, \mathrm{SD} \pm 0.45$, Figure 1$)$.

Frogs showed only one strike in the time in which Odonata took off. On two occasions, a second frog attack was observed. In one case the jumping frog aborted the catching action, leaving its mouth closed. In several other cases, it performed all behavioural elements until the final tongue flinging, although the prey was already gone. Frogs were seen to wait for optimal situations. When a Platynemis pennipes tandem was ovipositing, a frog observed the pair for minutes. Only when a harassing male of Ischnura elegans pushed the tandem male onto the water did the frog jump towards it, but the frog failed because the tandem male swung back very quickly to 


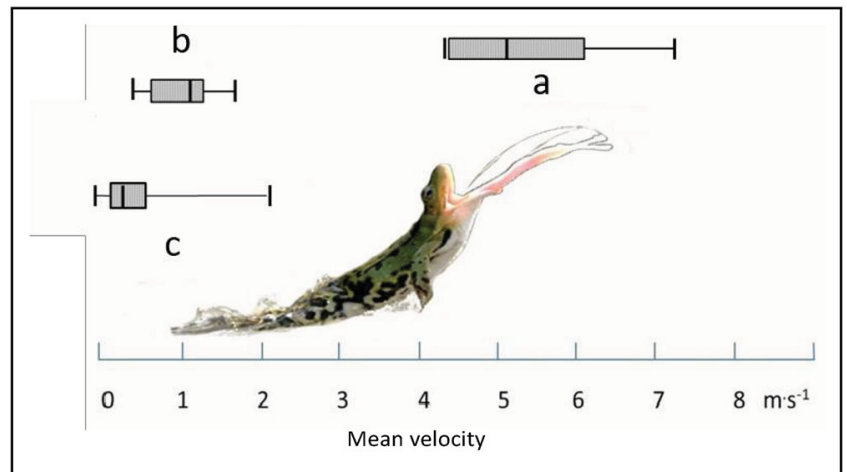

Figure 1. Maximal mean velocities $\left(\mathrm{m} \mathrm{s}^{-1}\right.$ ) over ground of: (a) a frog's tongue $(\mathrm{N}=11)$; (b) the bodies of jumping frogs $(\mathrm{N}=6)$; (c) at attacks on Odonata ovipositing or flying to oviposit and flight speeds of Odonata when fleeing after take-off $(\mathrm{N}=14$, of which: Anax imperator females $\mathrm{N}=9$; Coenagrion puella tandems $\mathrm{N}=3$; Libellula quadrimaculata females $\mathrm{N}=2$ ).
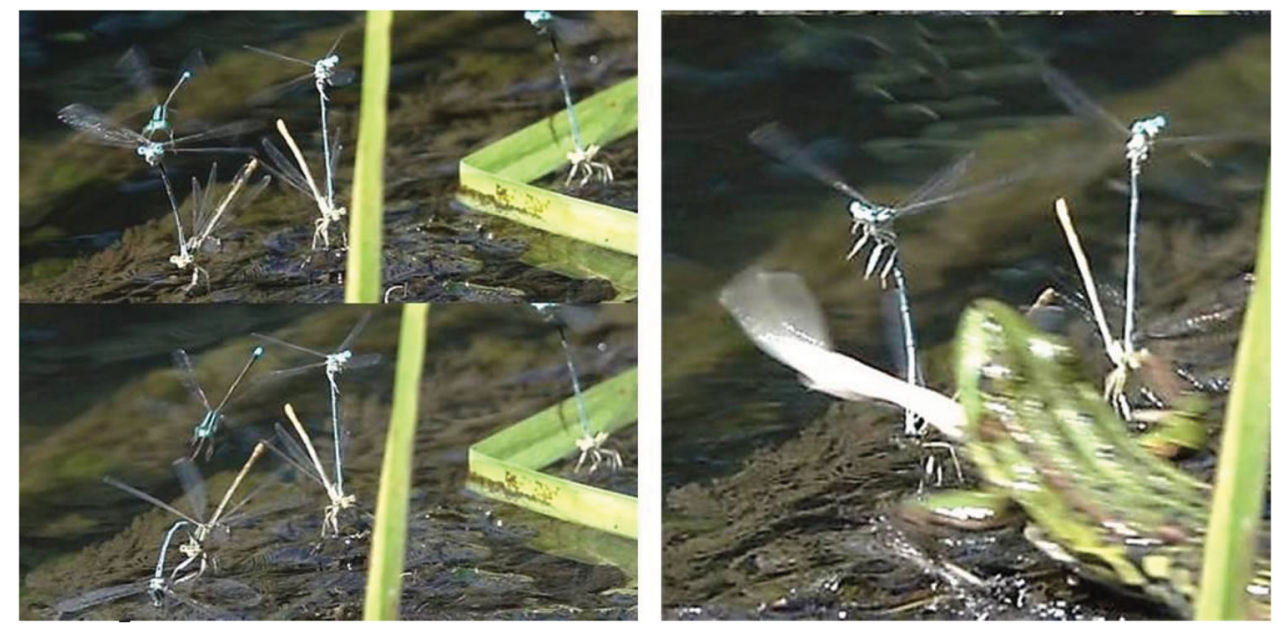

Figure 2. An Ischnura elegans male harassed a tandem male of Platycnemis pennipes (first left from top to bottom) and pushed him on the water $(2 \mathrm{nd})$ (time between these pictures $167 \times 10^{-3} \mathrm{~s}$ ). In this moment a frog targeted the tandem and jumped forward, but missed the tandem, which a split second before had switched back (right) (time between second and third picture $137.5 \times 10^{-3} \mathrm{~s}$ ) (from a film, $250 \mathrm{f} \mathrm{s}^{-1}$ ).

the upright position (Figure 2). In another case, a frog observed an earthworm hanging over it at about $30 \mathrm{~cm}$. The frog swam about $20 \mathrm{~cm}$ sideways, where it used a cushion of algae to jump and reached the prey.

\section{Prey capture with the tongue}

The tongue, when hitting the prey, especially sharp edges of wings, changed shape immediately. The thin split tip bent around the wing, attaching to its surface (Figures 3 ). When an ovipositing female of Aeshna cyanea started to flee in the moment of the advancing tongue she was hit and pulled down to the water (Figure 10). After an attack, an Anax imperator female was able to escape. She was flying forward initially and the mass of her moving body had enough energy to break away (Figure 3). 

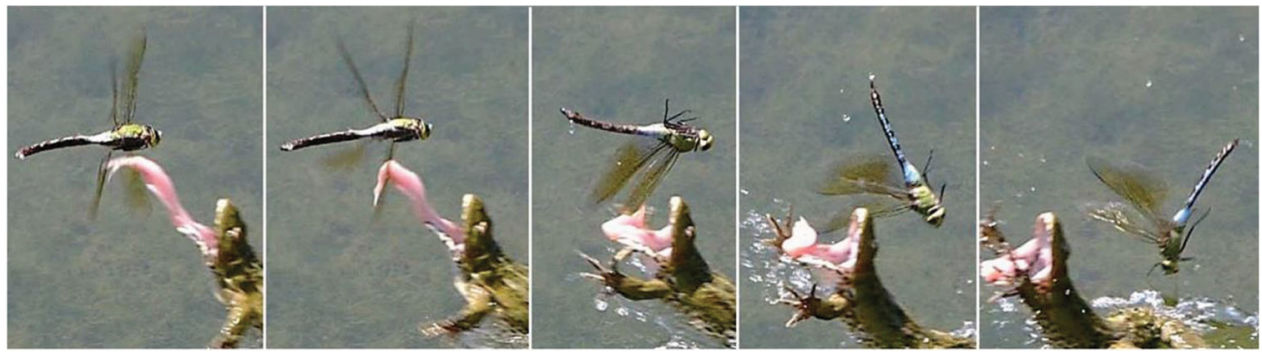

Figure 3. The frog's tongue hit the left forewing of an Anax imperator female approaching the water surface for oviposition. By the backstroke of this wing, the tongue was immediately turned sideways (2nd from left to right, time between 1 st and $2 \mathrm{nd}: 3.5 \times 10^{-3} \mathrm{~s}$ ). It held the dragonfly for another $35.6 \times 10^{-3} \mathrm{~s}$, but then lost it (from a film, $\left.200 \mathrm{f} \mathrm{s}^{-1}\right)$.

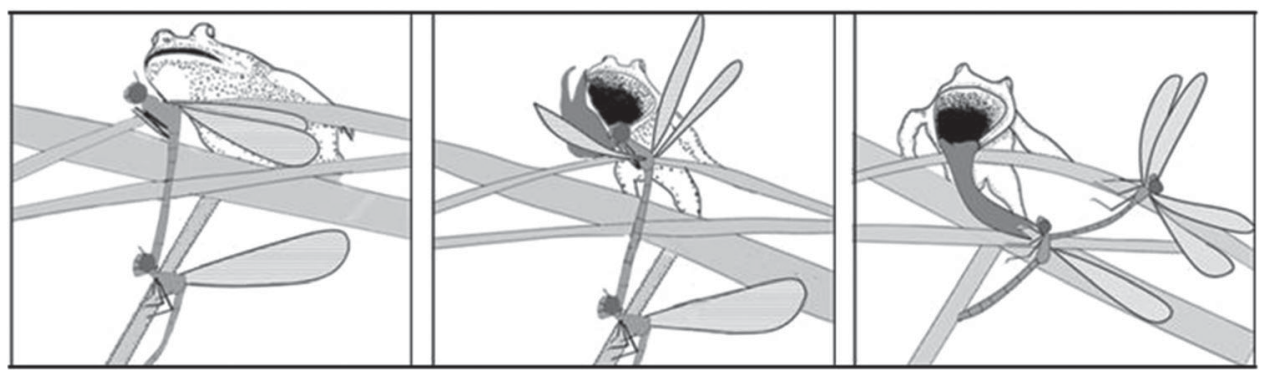

Figure 4. The direction of the frog's tongue-strike was corrected by the frog while already on the move. It was swinging to the left towards a fleeing tandem of Coenagrion puella, which was hidden behind a leaf before. The tongue is dark grey and the time between pictures (from left to right, all $\times 10^{-3} \mathrm{~s}$ ) is 13 and 22, respectively. Drawings after a film at $600 \mathrm{f} \mathrm{s}^{-1}$.

Shortly after take-off $\left(15-30 \times 10^{-3} \mathrm{~s}\right)$, frogs always closed their lower nictitating membrane. This was opened again after the head emerged from water (after $200-400 \times 10^{-3} \mathrm{~s}$ ). Eyesight at jump must have been at least partially preserved because, although the strike of the tongue mostly ran straight forward, in a few cases its direction was corrected while moving toward the prey by switching the front body or the tongue during the strike (Figure 4). In this case the targeted tandem male of Coenagrion puella switched sideways. Although the female's body was touched by the tongue, the damselflies escaped.

\section{Use of forelimbs}

After one rowing movement at the beginning of the jump, the forelimbs were outstretched for the pressing-in movement. The beginning of outstretching varied from 0.06 to $0.12 \mathrm{~s}$ ( $\mathrm{mean}=0.094$, $\mathrm{SD} \pm 0.03, \mathrm{~N}=12$ ) and the end of the pressing-in movement varied, too, depending on the success and distance to the prey (end after take-off; mean $=0.18 \mathrm{~s}, \mathrm{SD} \pm 0.057, \mathrm{~N}=9$ ). At very short catches only, from a sitting position, the frogs did not use their forelimbs. The pressingin movement was not finalized when the tongue or the forelimbs missed the prey. One male Enallagma cyathigerum was caught (reaction time $38 \times 10^{-3} \mathrm{~s}$, prey distance $95 \mathrm{~mm}$ ) sticking to the left side of the tongue, at which point the left forelimb performed a pressing-in movement into the mouth while the right forelimb remained outstretched. The damselfly was swallowed. 


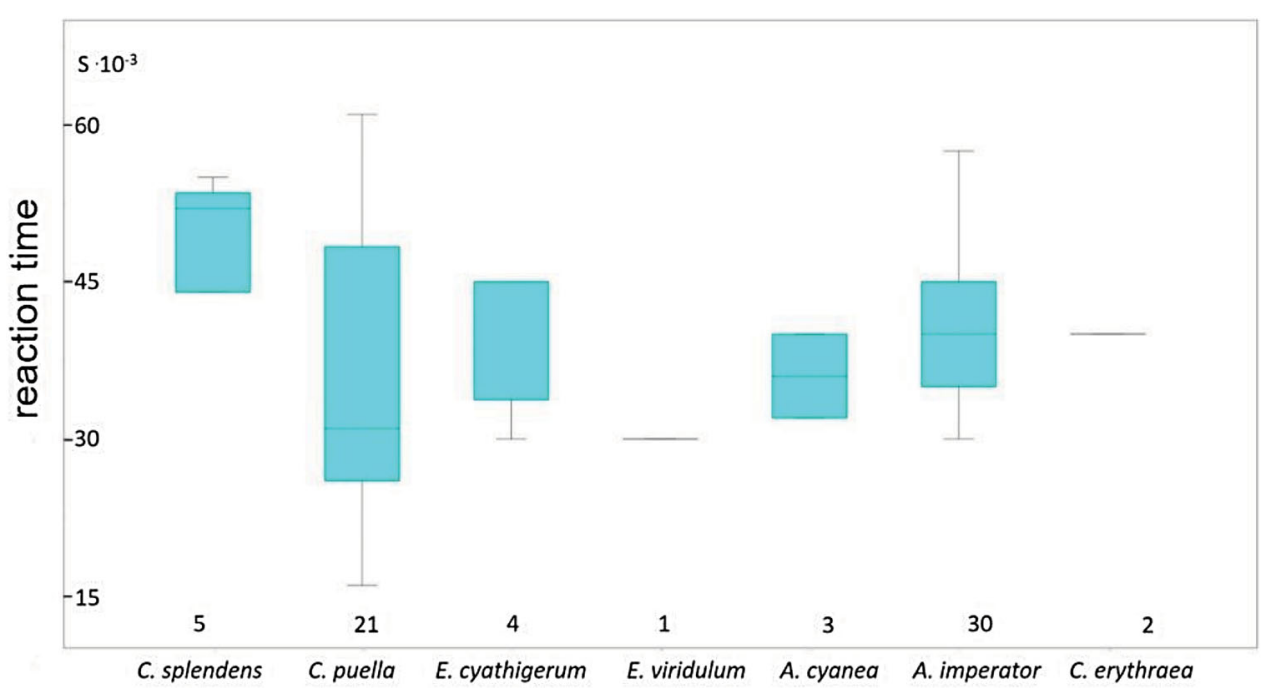

Figure 5. Reaction times, i.e. the time between first movement of jumping frog and of fleeing of endophytic ovipositing Odonata (excl. C. erythrea; boxplots). C. splendens = Calopteryx splendens (5 females); C. puella = Coenagrion puella (21 tandem males); E. cyathigerum $=$ Enallagma cyathigerum $(3$ tandems, 1 male $) ;$ E. viridulum $=$ Erythromma viridulum (1 male); A. cyanea = Aeshna cyanea (3 females); A. imperator = Anax imperator (30 females); C. erythraea $=$ Crocothemis erythraea (2 exophytic males).

\section{Reactions of Odonata}

When frogs jumped at a promising distance to the prey, all Odonata showed fleeing movements, indicated by fast wing movements. Reaction times of Odonata were around $45 \times 10^{-3} \mathrm{~s}$ (Figure 5).

Calopteryx splendens showed longer reaction times than three of the other species in the test. The $p$-values of reaction times of $C$. splendens to those of the other species in the order of Figure 5 (Erythromma viridulum and Crocothemis erythraea were not included, because there was only one case for each of these) were: to Coenagrion puella 0.046; to Enallagma cyathigerum 0.324; to Aeshna cyanea 0.024; to Anax imperator 0.032, Man-Whitney U. The standard deviation of C. puella is the largest. All other reaction times did not differ from each other.

\section{Zygoptera}

Calopteryx splendens At high densities females submerged for egg-laying. At middle and low densities, they oviposited above the water, flying around for searching suitable oviposition substrates. An above-water laying female being attacked accelerated from about $50 \mathrm{~cm} \mathrm{~s}^{-1}$ in normal flight to more than $200 \mathrm{~cm} \mathrm{~s}^{-1}$ in fleeing flight within three wing beats (about $0.1-0.5 \mathrm{~s}$, Figure 6). In four cases the damselflies accelerated to one side, sideways to the frog's jumping direction. When sitting, this was done by overturning. In one case a female turned over in $0.048 \mathrm{~s}$ (Figure 7). When flying, it was performed by sharp banking and a sudden change of flight direction as well as sideways to the frog's jump direction.

Enallagma cyathigerum Males lead females in tandem to oviposition sites. Often females oviposit under water, after detaching from the male. Frogs attacked perched and flying males and tandems. To escape, tandems swung around sideways to the jump direction and accelerated by in-phase beating on a nearly horizontal beat plane with highly inclined wings on the downstroke. The flight acceleration was high, reaching a speed of more than $200 \mathrm{~mm} \mathrm{~s}^{-1}$ at the first and 


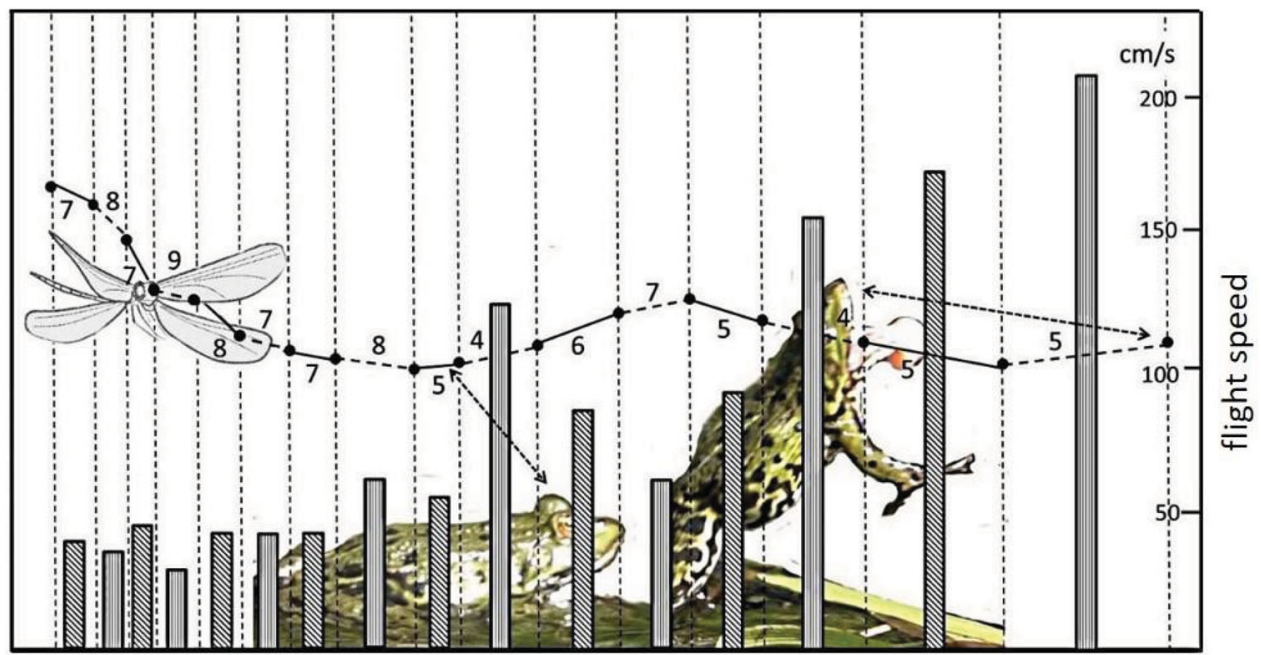

flight distances during successive up- and downstrokes

Figure 6. A female Calopteryx splendens attacked by a frog increased her flight speed. The left-hand arrow shows the beginning of the short jump; the position of the damselfly at the end of the picture is relative to the right-hand frog. Vertical banded bars give the flight speed during successive upstrokes; hatched bars represent flight speed during downstrokes. The line with dots marks the path of the body, measured at the frontline of the head, divided in downstrokes (solid segments) and upstrokes (broken segments). The numbers indicate the frame numbers at downstrokes (under the lines) and upstrokes (above the lines). One frame lasts $4 \times 10^{-3} \mathrm{~s}$. The distance covered by the female Calopteryx was about $20 \mathrm{~cm}$ (from a film, $250 \mathrm{f} \mathrm{s}^{-1}$ ).

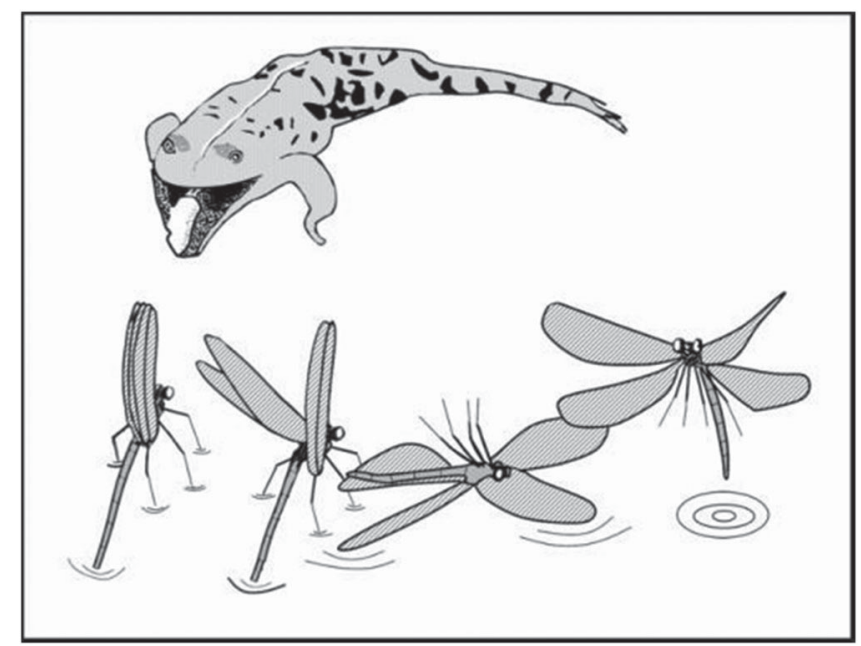

Figure 7. A female Calopteryx splendens ovipositing (left) escaped from a frog's attack. One fast wing beat in-phase downward (second from left) of the high inclined left wings caused overturning (middle). Time between phases (all $\left.\times 10^{-3} \mathrm{~s}\right): 60,60,224$.

nearly $500 \mathrm{~mm} \mathrm{~s}^{-1}$ at the second beat at a wing-beat frequency of $33.3 \mathrm{~Hz}$. Although the majority of attacked specimens were caught, some escaped, although the tongue had hit them. Females emerging from oviposition under water, being cooled and nearly immobile, were caught often and successfully nearly every time. However, on three occasions when an emerged damselfly was sitting on the head or body of the frog, the tongue could not reach it and the damselflies could take off after a short while. 


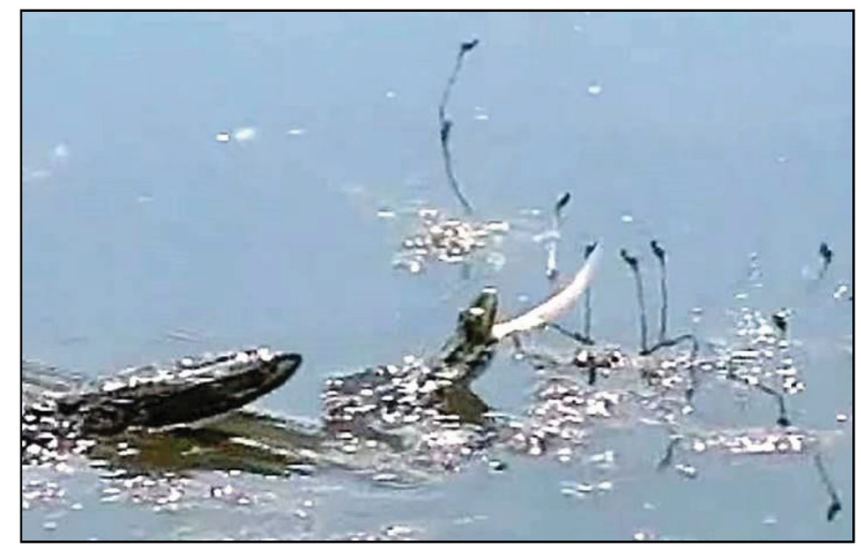

Figure 8. Two tandem pairs of Coenagrion puella flew across the frog's jump direction, one tandem, sitting before, to the left, the other ovipositing to the right. Three successive phases are combined here into one picture. The first phase of the jumping frog (left) corresponds to the two tandems in the middle sitting opposite; the frog with outstretched tongue corresponds to the tandems second from left and second from right. The sitting left tandem flew farther in the same time than the right one. Here only the male swung sideward out of the reach of the frog. Time between phases: 50, 90, all $\times 10^{-3} \mathrm{~s}$ (from a film, $300 \mathrm{f} \mathrm{s}^{-1}$ ).

Coenagrion puella Tandems of Coenagrion puella only laid eggs above the surface, often in aggregations $(\mathrm{N}=20)$ of 5-40 pairs. They often showed early escape upon recognition of slow approaches by frogs, mostly initiated by the male, and evasive, fast escape movements sideways to the jump direction. When a tandem pair was sitting, the escape was done faster with movement away achieving longer distances than in an ovipositing pair (Figure 8).

When the females were not able to detach the endophytic ovipositing abdomen fast enough, the males only swung sideward to get out of reach. One male covered a distance of $3 \mathrm{~cm}$ in $8.4 \times 10^{-3} \mathrm{~s}$ by an angle change from upright position of the body to $60^{\circ}$ (male on the right in Figure 9). In three catching attempts, the frog dumped tandems, but when they separated it shovelled individuals into its mouth with its forelegs.

\section{Anisoptera}

One female of A. mixta was caught. Aeshna cyanea males, when searching for ovipositing females, were attacked by frogs from a distance of $10-20 \mathrm{~cm}$ several times, but never successfully. Females laid eggs in water plants or moist bank structures such as moss or tree roots. Frogs hunted for them from the waterside. Most of the escapes followed the same pattern: after the frog's take-off, the dragonflies turned over to one side and took off in backward flight by inphase beating for three or four beats with high-inclined wings at the downstrokes. One female was in line with the jumping line of the frog. She immediately beat all wings in phase and accelerated sideways, generating a half turnover, bringing the dragonfly out of the jumping line of about $2 \mathrm{~cm}$ within $0.037 \mathrm{~s}$. The frog crashed onto her body with its left foreleg, but as this leg was retracted, the dragonfly could escape. Another female of A. cyanea reacted too late in the same place at $20.00 \mathrm{pm}$ and was caught.

One female was caught when the tongue hit a wing shortly after take-off as the dragonfly just began to produce power to take off (Figure 10). The tongue turned around the wing, clinging to its surface, and pulled the dragonfly down.

Anax imperator Anax imperator females laid eggs in water plants and often in dead stems drifting on the surface. They often recognized approaching frogs early and took off before attacks. 


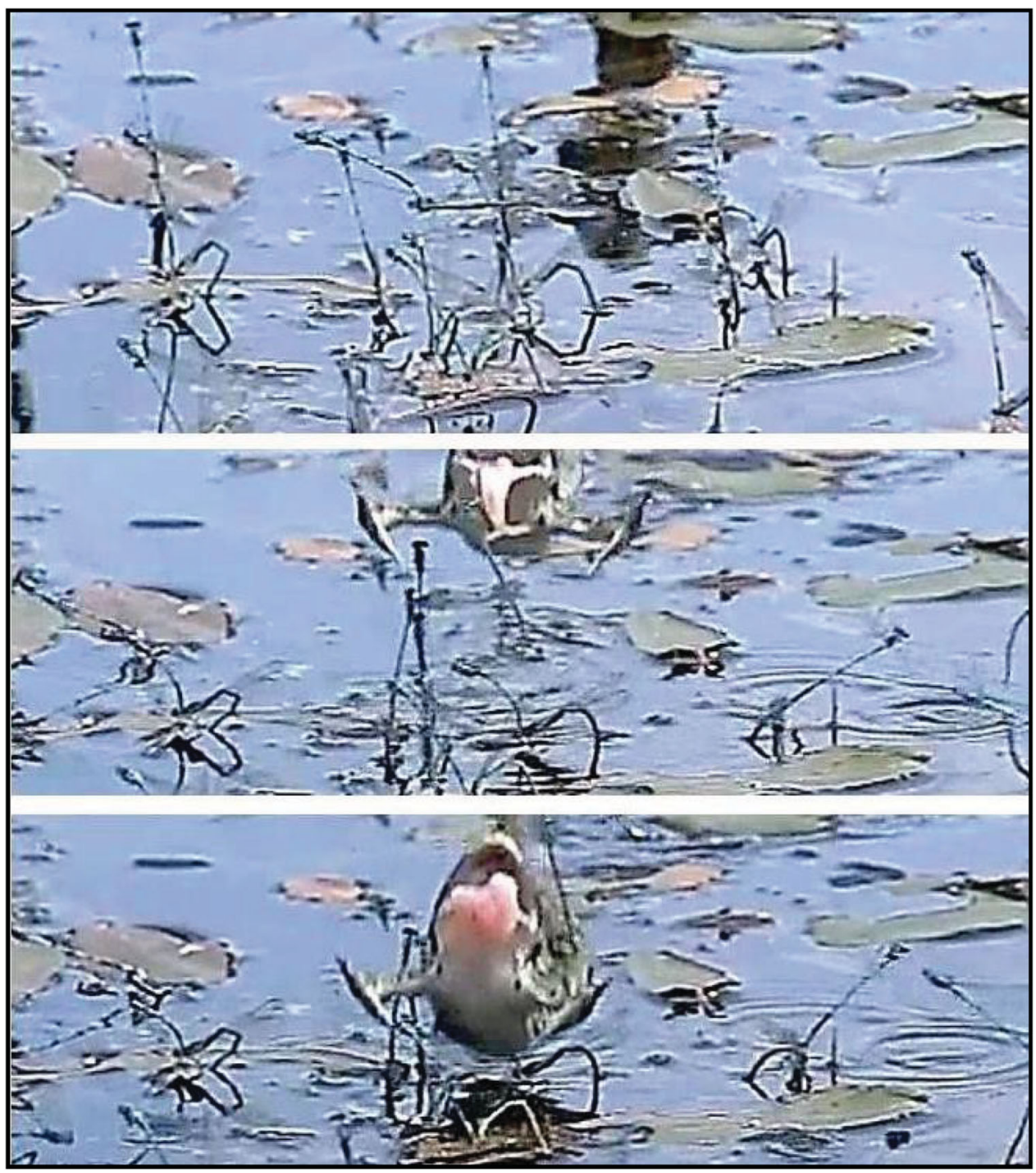

Figure 9. A frog jumped into an aggregation of 11 ovipositing Coenagrion puella tandems. As it approached (beginning at the top), all tandem males were in an upright position. After $140 \times .10^{-3} \mathrm{~s}$ the tandem pairs to the side of the jumping line swung to the right or left away from the frog. The tandem pairs in the jumping line did not flee to one side and were dumped into the water by the frog's body (the third picture is $23 \times 10^{-3} \mathrm{~s}$ after the second) and some of them later were shovelled in by the forelegs. The frog devoured at least three individuals (from a film at $600 \mathrm{f} \mathrm{s}^{-1}$ ).

But when attacked, they mostly escaped. Only about $8 \%$ were eaten. They performed sideward turn-overs very fast, accelerated strongly and even when hit and pulled under water, they could escape by strong wing beats.

\section{Attacks at ovipositing Anisoptera}

The reaction times of females were $40.77 \times 10^{-3} \mathrm{~s}(\mathrm{SD}=8.25, \mathrm{~N}=24)$. By acceleration, ovipositing Anax imperator females escaped when sitting sideways to the frog's jump direction. They beat their high-inclined wings in-phase at wide beat angles. During these manoeuvres, 

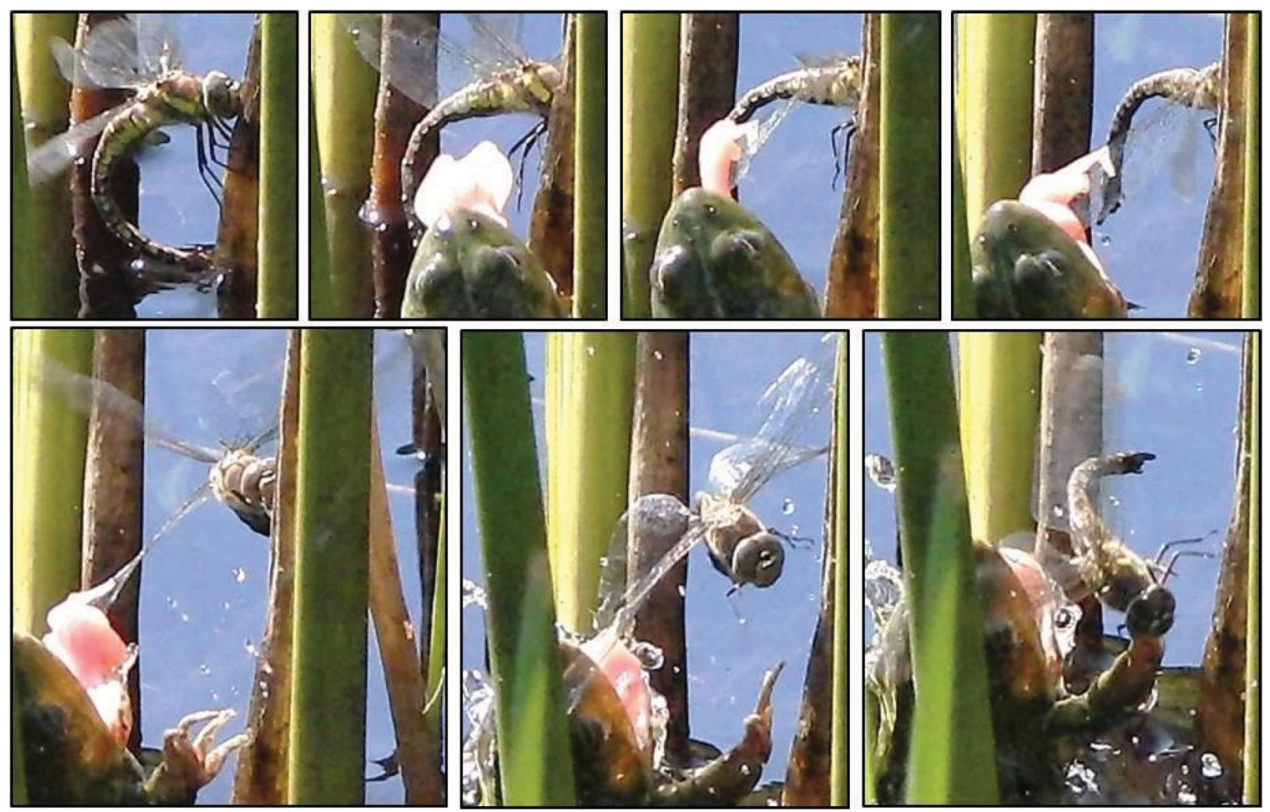

Figure 10. A frog caught an ovipositing Aeshna mixta. The dragonfly took off (second picture from left, top row), just before the tongue hit the right forewing (top row, third picture). Only by its left tip of the tongue the frog pulled the dragonfly down onto the water (third, fourth and fifth pictures). Photos out of a series at $64 \mathrm{f} \mathrm{s}^{-1}$.

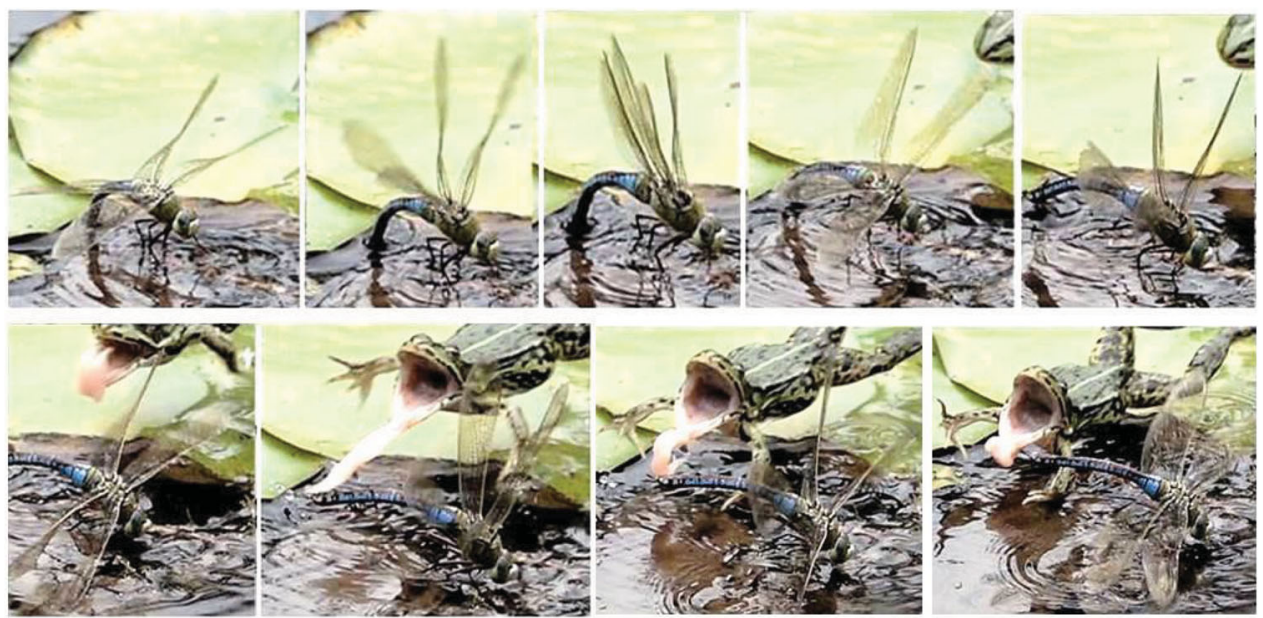

Figure 11. An Anax imperator female escaped a frog's attack by accelerating forward: she was flapping her wings at wide stroke angles (at upstrokes nearly together) with very short upstrokes and highly inclined wings. Beginning on the left side, top row: first: beginning of upstroke, third: end of upstroke, fourth: end of downstroke, fifth: middle of upstroke. Bottom row: first: end of downstroke, third: middle of upstroke; fourth: end of downstroke. At downstrokes the wings were slightly inclined. Fore and hind wings were beaten in-phase. The fleeing direction was rectangular to the frog's jump and was directed downwards. Time between pictures $\left(\right.$ all $\left.\times 10^{-3} \mathrm{~s}\right): 8,6,10,10,14,12,16,14$ (pictures from a film at $500 \mathrm{f} \mathrm{s}^{-1}$ ).

all four wings nearly touched each other at the beginning of the downstroke above the body (Figure 11). The upstrokes at escape flight were very short. They lasted on average $7 \times 10^{-3} \mathrm{~s}$, in contrast to $12 \times 10^{-3} \mathrm{~s}$ in normal take-off. 

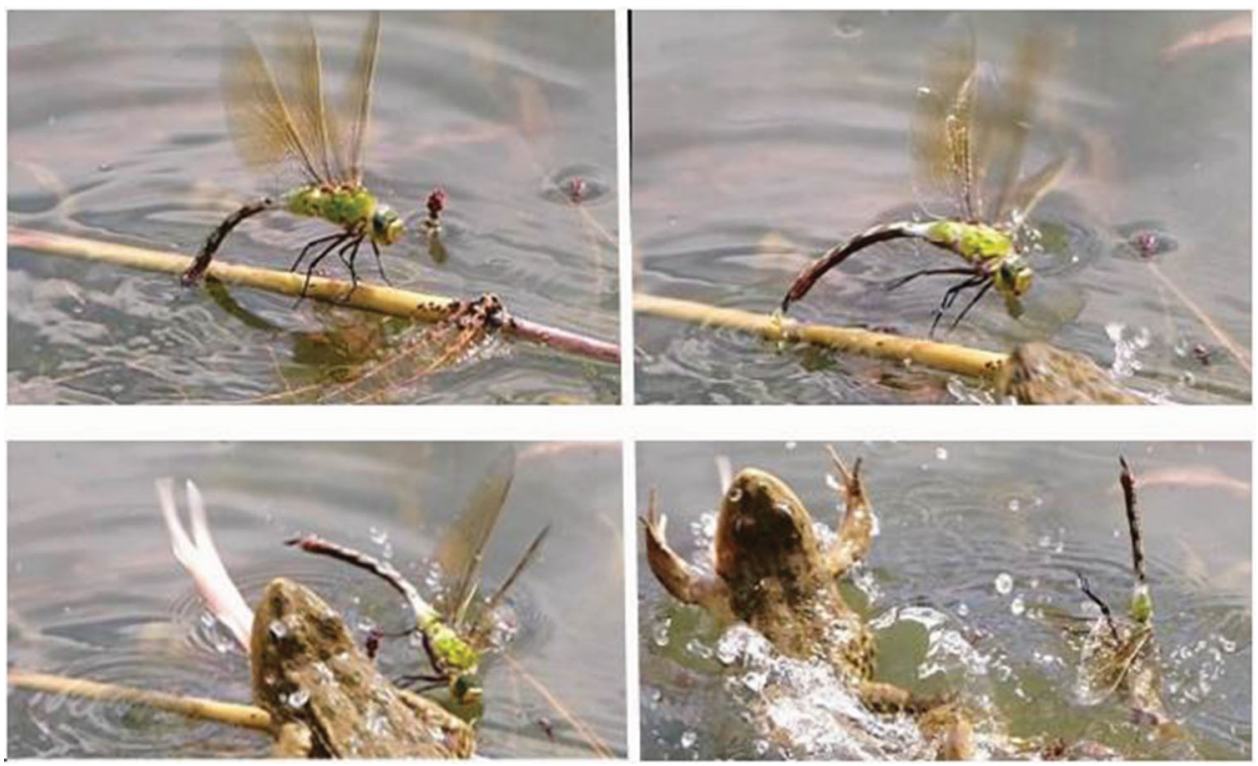

Figure 12. Anax imperator female sitting in line with the attacking frog turned over to the left and escaped (from top left to right, then bottom left to right). In the first frame, Anax clapped its wings almost together for the next beat at high amplitude. Time between pictures (all $\times 10^{-3} \mathrm{~s}$ ): 16.7, 24.2, 58.3 (filmed with $200 \mathrm{f} \mathrm{s}^{-1}$ ).
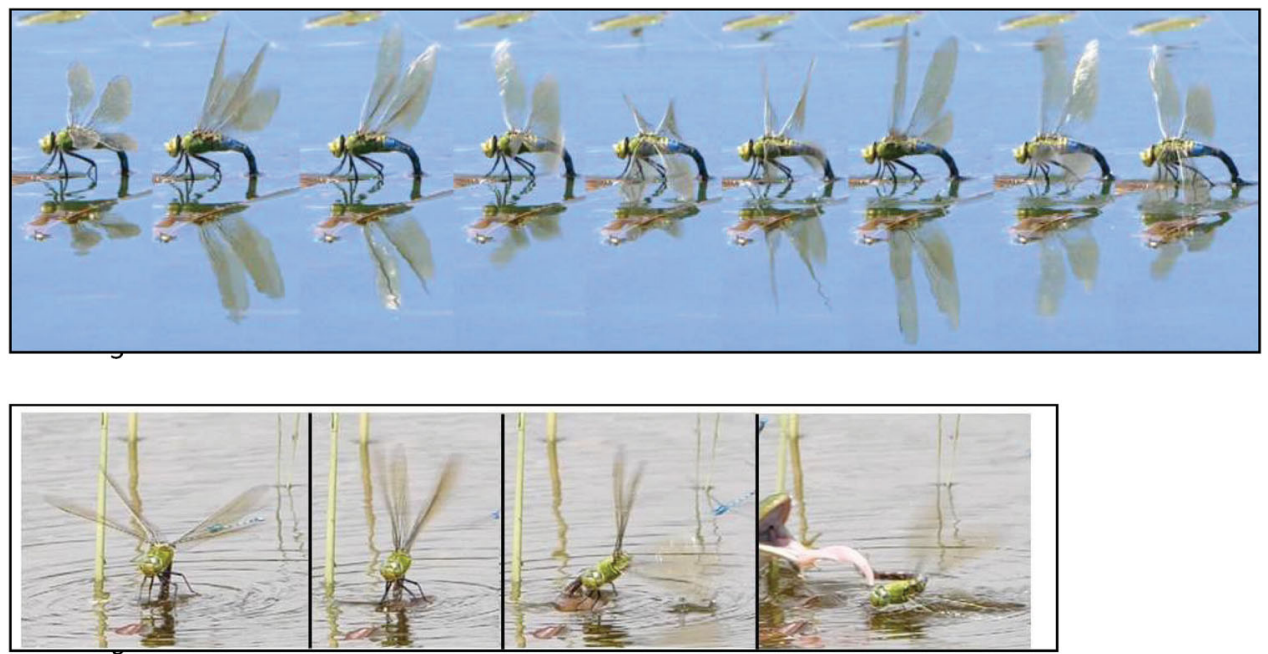

Figure 13. Top: Wing movements to turn over to left of Anax imperator ovipositing at a frog attack from left. From left to right: first: normal position during ovipositing; second: the upstroke of the right wings went higher; third: the left wings were beaten earlier downward at small angles of attack; fourth: the right wings were beaten downward more sideways at high angles; fifth and sixth: during upstrokes the wings were tilted to get slightly inclined. Bottom: In phase 3 (from left to right) the left wings are beaten lower than the right wings and very fast (blurred wings) (from films $200 \mathrm{f} \mathrm{s}^{-1}$ ).

When sitting in line with the frog's jump the dragonflies showed a sudden overturning to one side (Figure 12). The beating in turning over was always very similar: the low-inclined wings to the turning side were beaten downwards, while the others were highly inclined and beat more horizontally (Figure 13). Turning over was very quick. In Anax imperator it lasted, in one case, at a prey distance of $12 \mathrm{~cm}$ only $0.1 \mathrm{~s}$ to travel a sideward distance of $3-4 \mathrm{~cm}$ to the frog. In another case (prey distance ca. $10 \mathrm{~cm}$ ) it took $0.065 \mathrm{~s}$ to get out of reach sideways. 


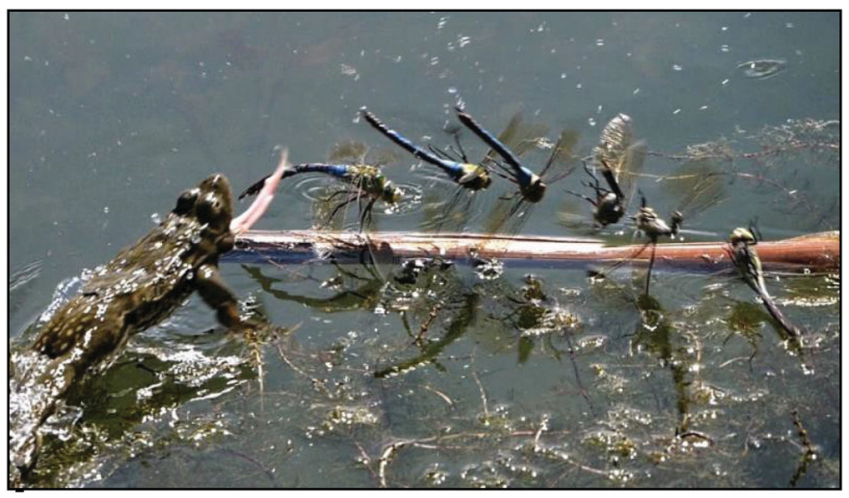

Figure 14. An Anax imperator female escaped by turning over forward, sideways to the frog's jump direction. Six phases of the fleeing dragonfly from a film at $200 \mathrm{f} \mathrm{s}^{-1}$ were combined in this picture. The frog corresponds to the first dragonfly on the left. The frog landed where the third dragonfly is in the picture (from left to right). At the position of the right phase the dragonfly took off. Time between phases (all $\times 10^{-3} \mathrm{~s}$ ): 45, 25, 30, 15, 30 (filmed with $200 \mathrm{f} \mathrm{s}^{-1}$ ).

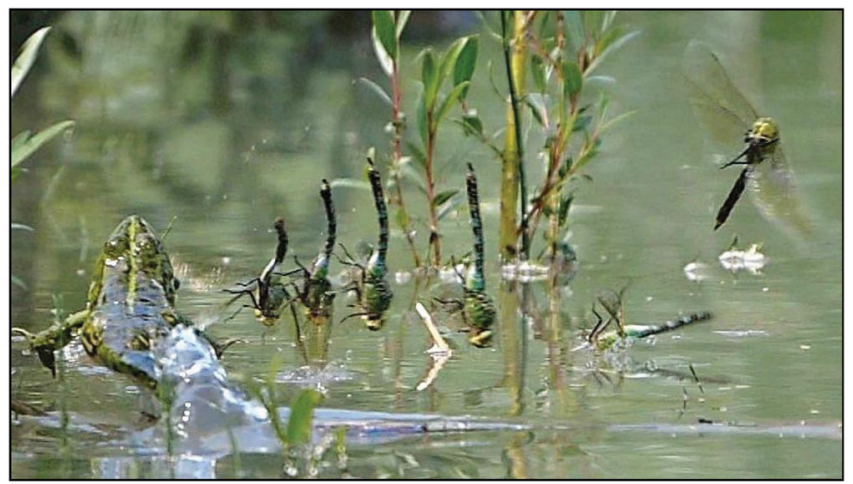

Figure 15. An Anax imperator female escaped by turning over to the right. She then flew head down and backwards for five beats. Six pictures from a film were combined. The jumping frog corresponds to the first dragonfly (from left to right, time between phases (all $\times 10^{-3} \mathrm{~s}$ ): 20, 20, 30, 55, 505 (filmed with $200 \mathrm{f} \mathrm{s}^{-1}$ ).

Turning over forward to escape occurred when the female was sitting rectangular to the frog's jump and only $8 \mathrm{~cm}$ from a lurking frog (Figure 14). This was done by six wing beats at a frequency of $39 \mathrm{~Hz}$. To get the turning momentum the forewings and hind wings were beaten differently: the forewings were beaten low-inclined, while the hind wings were beaten highly inclined and at wide stroke angles. This resulted in a turning round the transversal axis. Additionally, the stroke paths of both wings on the left side were higher than on the right side, so that the dragonfly moved not straight but on a curved path - away from the frog (Figure 14). This way, the female got away by $17 \mathrm{~cm}$ in $100 \times 10^{-3} \mathrm{~s}$. After overturning on the water surface, the female took off after another $150 \times 10^{-3} \mathrm{~s}$. Taking off from water was successful, too, in all other cases $(\mathrm{N}=30)$.

In two cases the Anax imperator females flew backward in head-down position. In one case (Figure 15), she first turned over to one side. It took $59 \times 10^{-3} \mathrm{~s}$ to get a distance of $3 \mathrm{~cm}$ to the strike path of the tongue. Afterwards she flew backward to this side in a head-down position. In this flight-posture this female reached a distance of $13.8 \mathrm{~cm}$ in $0.44 \mathrm{~s}$ by five beats. The flight velocity during this backward flight head-down was $313.6 \mathrm{~mm} \mathrm{~s}^{-1}$. The wing beat frequencies for the first three strokes away from the stick sideways before head-down flight were 40, 50 and $50 \mathrm{~Hz}$, and during head-down flight the five strokes were at $40 \mathrm{~Hz}$. 


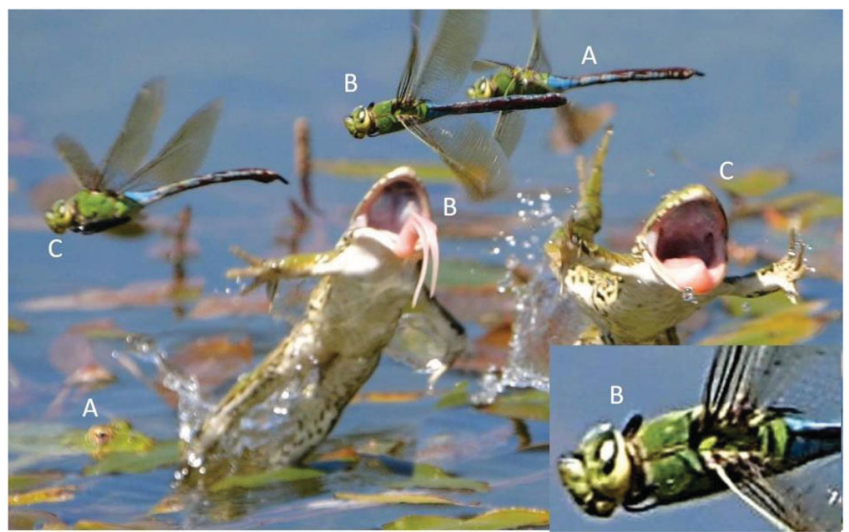

Figure 16. A frog missed a flying Anax imperator female (combination of three pictures from a film at $200 \mathrm{f} \mathrm{s}^{-1}$ ). (Same letters correspond to simultaneous phases of frog and Anax). From sitting the frog (A) jumped, dashing its tongue (B). At the same time A. imperator banked its body (B). In the small enlargement at bottom right (B) the banking is visible looking on the top of the switched thorax, while the head stays horizontal). By beating in this new beating plane, the dragonfly got nearer to the camera, visibly in focus (middle Anax B). The position of the left Anax (C) corresponds to the position of the right frog $(\mathrm{C})$. Time between phases (Anax from right to left): (all . $\left.\times 10^{-3} \mathrm{~s}\right) 100.8$, 71.7. (filmed with $200 \mathrm{f} \mathrm{s}^{-1}$ ).

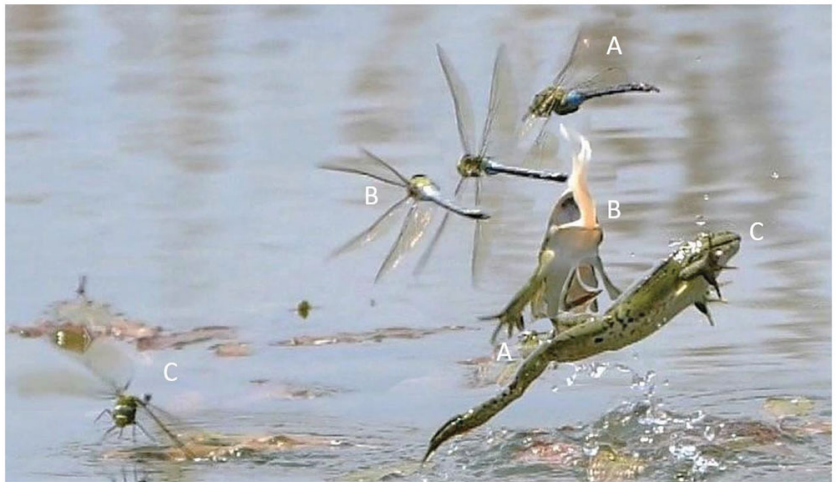

Figure 17. Banking to escape: four successive phases of an Anax imperator female are combined in one picture (same letters correspond to simultaneous phases of frog and Anax). The frog jumped upwards from the middle and then to the right. The dragonfly flew from right to left. She escaped by banking, switching the thorax to the left (second phase from right, no corresponding frog) getting a new beating plane. This together with very wide beat angles $(=$ amplitudes, B) accelerated the dragonfly away from the frog. Anax touching the water (C) (bottom, left) corresponds to the falling frog (C, bottom, right). Time between phases of the dragonfly: $31.3,13.9,104.2 \times 10^{-3} \mathrm{~s}$ (from a film at $200 \mathrm{f} \mathrm{s}^{-1}$ ).

\section{Attacks on flying Anax imperator}

Looking for an ovipositing site, Anax imperator females cruised at low altitude above the water's surface, where they were also attacked. Two of six flying females were touched by the jumping frog's tongue but not caught. All flying individuals showed similar escape moves: fast banking, in-phase beating for the first 3-4 beats with high-inclined wings and wide stroke angles (Figure $16,17)$.

This led to a sudden distance gain away from the frog's jump path. One female accelerated (in $25 \times 10^{-3}$ s steps) from 280 over 800 and 1440 and 1600 to $1640 \mathrm{~mm} \mathrm{~s}^{-1}$. 
$10^{-3} \mathrm{~s}$

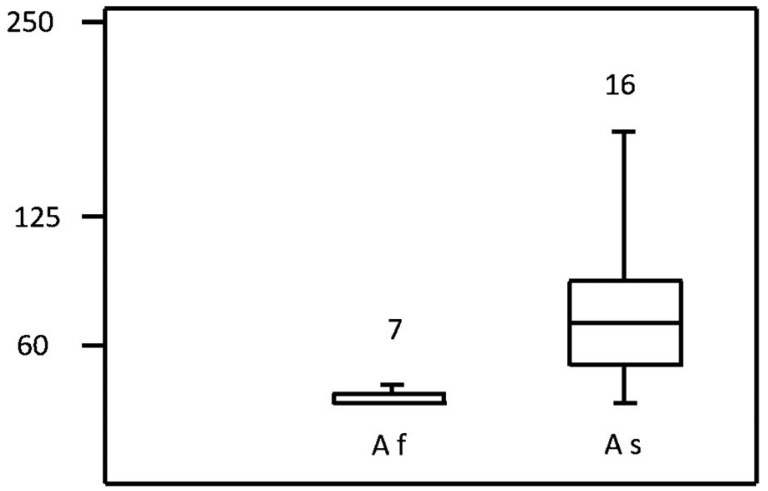

Figure 18. Time (boxplots) of Anax imperator females between frogs jump begin and take-off after beginning of frogs jump. Af $=$ females were flying, As $=$ females were sitting. Numbers are cases.

Table 2. Frog capture rates of different Odonata species. In Calopteryx splendens, single endophytic ovipositing females and single males (5), in Enallagma cyathigerum tandems, males and females were taken together. Coenagrion puella were tandems, Sympetrum sp.: most tandem pairs were of S. striolatum, but several could not be determined. In Anax imperator 16 females were caught but only 11 of them were eaten; the others escaped. Libellulidae: Libellula quadrimaculata (16 females), Orthetrum cancellatum (3 females), Crocothemis erythrea (2 males).

\begin{tabular}{lcccc}
\hline Species & Catch attempts & Catch success & Caught individuals & Capture rate $(\%)$ \\
\hline Zygoptera & & & & 36.4 \\
Calopteryx splendens & 11 & 4 & Not determined & 50 \\
Coenagrion puella & 26 & 13 & 7 & 35.3 \\
Enallagma cyathigerum & 17 & 6 & $11(16)$ & 7.9 \\
Anisoptera & 140 & 16 & 49 & 8.8 \\
Anax imperator & 398 & 35 & 0 & 0 \\
Sympetrum striolatum & 21 & 0 & & \\
Libellulidae & & & & \\
\hline
\end{tabular}

\section{Already caught but escaping}

When being hit by the frog's tongue A. imperator could free itself by powerful wing strokes. In one case the frog hit the body of A. imperator and inhibited a turning-over of the dragonfly by its tongue. But the female beat her wings down on the frog's head at wide angles and a frequency of $33 \mathrm{~Hz}$. Taking the same stem that she had previously oviposited in as a platform, she could take off and could get free after $0.07 \mathrm{~s}$. The time to take-off from beginning of the frog's jump was very short in flying Anax females and longer, when the females were sitting (Figure 18).

Five times (out of 16, Table 2), A. imperator females were brought under water, but could emerge for taking off. The battles under water to get free took a long time: in one case it lasted $3.46 \mathrm{~s}$ from the beginning of the frog's jump to take-off; another time it was $2.14 \mathrm{~s}$, while takeoffs without being pulled under water happened much earlier. When being attacked in flight acceleration away from the frog occurred after $0.2 \mathrm{~s}(\mathrm{SD}=0.096 \mathrm{~N}=6)$, while after attacks when ovipositing sitting, take-off happened after $0.43 \mathrm{~s}(\mathrm{SD}=0.25, \mathrm{~N}=14)$. Times of all three cases were different, the last two were tested ( $t$-test $p=0.038$ ).

\section{Attacks on Sympetrum-tandems}

Sympetrum species mostly oviposited in tandem. When recognizing the jumping frog, the male often changed his beat pattern. The female did as well, but not as much as the male. The male 


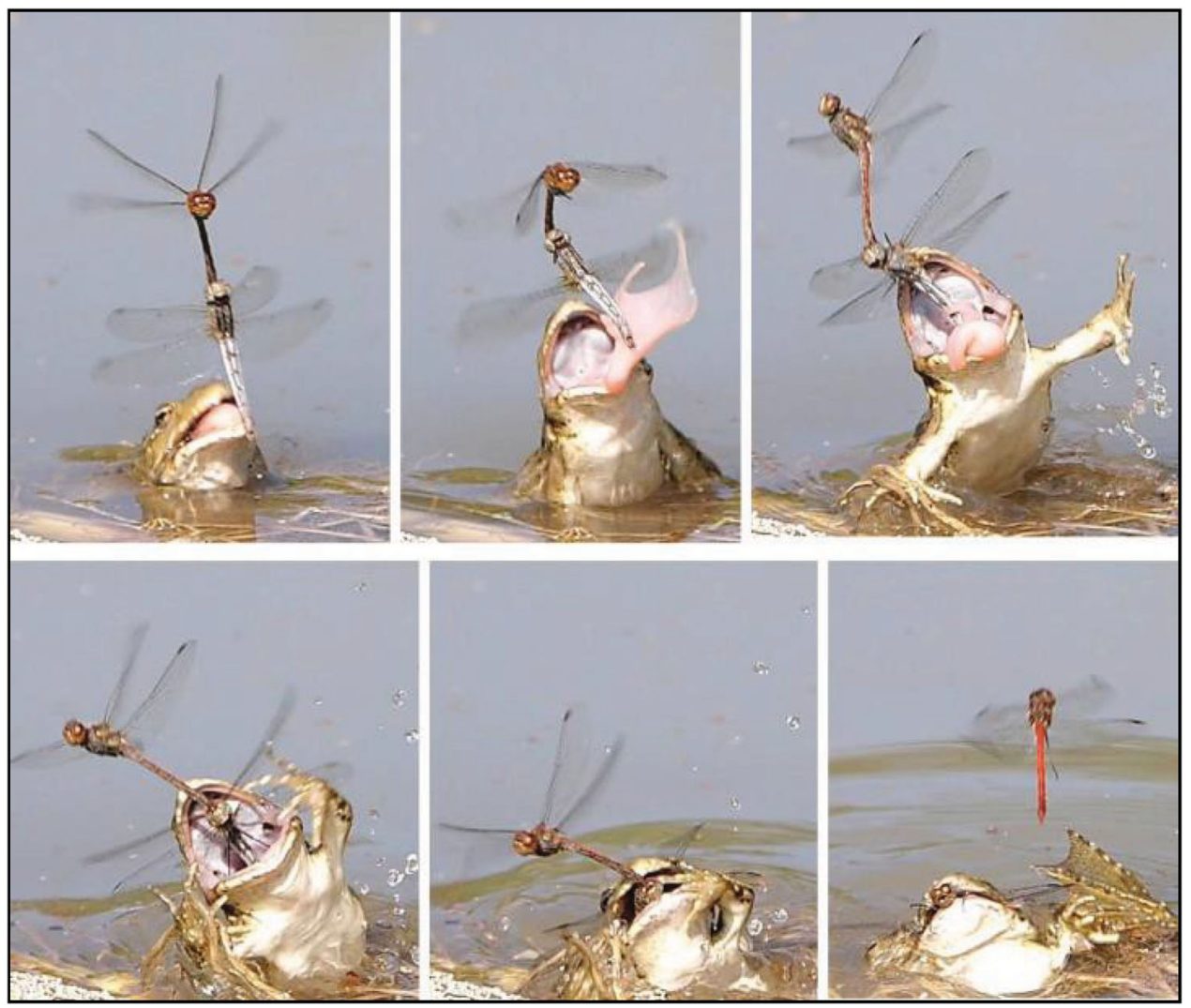

Figure 19. A frog caught a female from a tandem pair of Sympetrum striolatum. The tongue wrapped around the female's abdomen (second and third phase, top from left to right). After retracting it (fourth phase) the frog stuffed the female in its mouth. The male escaped (sixth phase, bottom right). Time between pictures (all $\times .10^{-3} \mathrm{~s}: 16.7,33.4,27.5$, 24.2, 50 (from a film, $200 \mathrm{f} \mathrm{s}^{-1}$ ).

beat his wings at wider angles than before. The wing-beat frequencies increased from 40 to 50 and $66.7 \mathrm{~Hz}$ and two beats after take-off were in-phase and the tandem escaped.

When a tandem pair did not recognize the frog, it sometimes came too close and the pair were captured (Figure 19). When the tandem pair of Sympetrum striolatum was just in elevating flight, after having dipped for oviposition, no evasive measures of the dragonflies were observed. They just continued flying upward. When the frog missed the tandem on its erratic flight path, the dragonflies finished their manoeuvre for egg-laying and flew fast upward, often in backward flight. Tandems turned to that position immediately after the frog had begun jumping.

\section{Capture rate}

In backward flight at high angles of attack maximal accelerations were reached. A frog attacked a single ovipositing Leucorrhinia pectoralis female, flying on the spot. She reached $700 \mathrm{~mm} . \mathrm{s}^{-1}$ in only $30 \times 10^{-3} \mathrm{~s}$ whereas a sitting Anax imperator female reached only $250 \mathrm{~mm} . \mathrm{s}^{-1}$ in the same time by forward flight.

In 21 hunts on Libellula quadrimaculata, Orthetrum cancellatum and Crocothemis erythrea females, while dipping on the water for oviposition, frogs had no success.

The capture rate of frogs in general was higher in Zygoptera (ca. 35-50\%) than in Anisoptera (ca. 0-9\%). The exophytic ovipositing Anisoptera species Libellula quadrimaculata, Orthetrum 


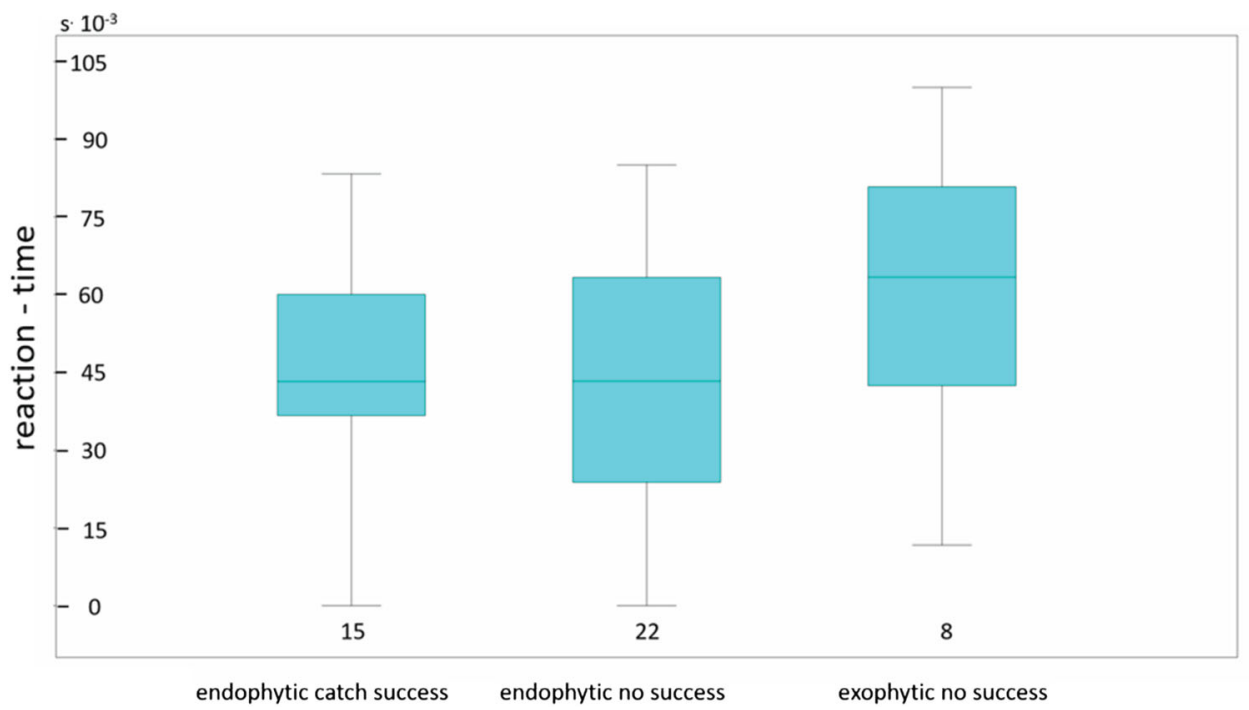

Figure 20. Reaction times (boxplots, ordinate) of endophytic ovipositing Odonata species, that were caught (catch success), those that were not caught (no success) and of exophytic ovipositing species, that were not caught (no success). Numbers $=\mathrm{n}$. First boxplot $\mathrm{n}=15$ Coenagrion puella tandem pairs, second boxplot $\mathrm{n}=22$ C. puella tandem pairs, third boxplot $\mathrm{n}=5$ Anax imperator females and $\mathrm{n}=3$ Libellula quadrimaculata females were analysed.

cancellatum and Crocothemis erythrea (Libellulidae) laying eggs as a single female escaped in all of the 21 filmed cases, while the tandem egg-laying Sympetrum sp. suffered a capture rate of $8.8 \%$, similar to that of single endophytic ovipositing Anax imperator females (Table 2).

The catching success was not correlated to reaction times. Those Odonata ovipositing endophytically and which were caught did not have longer reaction times than those who were not caught. Only exophytic ovipositing species seem to have slightly longer reaction times (but this differ not statistically, $t$-test) (Figure 20).

\section{Discussion}

This is the first paper publishing data of systematically analysed video showing frog attacks on Odonata. The results will be discussed regarding reaction time and special manoeuvres by the odonates and capture rates by the frogs.

\section{Reaction times}

There were only a few cases where the odonates overlooked the predator. The vast majority reacted very quickly. Females of Calopteryx splendens showed longer reaction times than all other measured species. Probably their high advance ratio (distance per wing beat, Ellington, 1984a, 1984b; Rüppell, 1989) allowed them to take flight later than other species with lower advance ratios. Variations in reaction times were high in A. imperator (maximum standard deviations were $19.5 \%$ from mean values), and highest in $C$. puella (up to $43 \%$ ). The reaction time of caught individuals in all species did not differ from those of escaping individuals. Some Anax imperator females recognized the frog very early and took flight before the sneaking 
frog jumped. This was the case in Coenagrion puella, too, especially when they oviposited in aggregation.

\section{Special flight and escape manoeuvres}

This investigation showed that the outcome of the old arms race between Odonata and frogs, developed over some hundred million years, is often decided by being faster, measured in milliseconds, and achieving greater distances, measured in millimetres.

To get out of reach of the frog, high accelerations (also in Rüppell \& Hilfert-Rüppell, 2020) and sudden changes of flight directions were observed. When frogs were jumping at close range, Odonata showed different escape manoeuvres, depending on the body orientation of the opponents. Sitting horizontally and perpendicular to the frog's jump direction, the Odonata accelerated forward when the frog approached from behind. When it approached the head of the prey they flew backward. Odonata also fled backwards when sitting vertically on plants as many Zygoptera do or on bank structures as Aeshna cyanea do when ovipositing. To assess this, we measured the increase of beat frequencies, change to in-phase flapping of both wing-pairs, and beating toward the approaching frog with high inclined wings. Often an increase of beat amplitudes was observed, especially in Zygoptera and in large Anisoptera, such as Anax imperator and Aeshna cyanea. In these species, all four wings were nearly touching each other at the end of upstrokes. This likely generated additional lift, as suggested from Weis-Fogh (1973) by the clap-and-fling mechanism. In one case, this was incremented: Anax imperator females showed forward overturning when sitting across to get away. To do this forewings and hind wings differed in their kinematics: the hindwings beat equally on both sides, but at higher angles of attack than the forewings. The result was that both hind wings produced more lift than the forewings and the dragonfly overturned forward.

When the prey's position was in line with the predator's jump, the fleeing manoeuvres were different - they always exhibited a quick sideward overturning. Then the wings, directed to the frog, were beaten at a higher incline than the others. Without trying to discuss aerodynamic details (Bomphrey, Nakata, Henningsson, \& Lin, 2016) we can be sure that the high-inclined wings generated more lift on this side, catapulting the odonate sideways, away from the frog. Often a fall into the water resulted, but due to their hydrophobic cuticle nearly all targeted Odonata could take off again. Calopteryx splendens females could take off with only $2-3$ beats, while the larger aeshnids needed 5-8 beats and double the time. But this time was sufficient to escape. We never saw a successful second strike from a frog.

Those Odonata ovipositing endophytically turned over sideways very quickly because their attachment point of the abdomen in plants enhanced the turning moment caused by the asymmetrical wing beats. This was the case in species ovipositing alone or in tandem pairs. Flying individuals tried to escape by sideways fleeing as well. They did this by very quickly banking the body, resulting in the wash of the wings being directed away from the jump direction of the frog, pushing them away. Even males in tandem with females ovipositing (Sympetrum) swung sideways. Because of this action, within hundreds of seconds, the pair could fly several centimetres, enough to escape. Female A. imperator showed the most exceptional way of fleeing when they overturned to the right and then performed a headstand in flight; in one case, a female travelled in this position for $14 \mathrm{~cm}$. We are not aware of any other insect exhibiting such an outstanding manoeuvre.

The powerful A. imperator may oviposit on open water easily visible to frogs. They have powerful flight manoeuvres and even when hit by a frog, they often can free themselves by strong wing beats. These beats were directed toward the frog, obviously overcoming the holding force of the frog's tongue. Even underwater Anax females freed themselves by these strong wing beats. 


\section{Capture rate}

The frog's tongue, its forelegs and its body were successfully utilized for capturing prey. In Zygoptera, it was the frog's tongue which achieved the greatest success. The holding force of the tongue, especially in large species, was not strong enough to pull down an Anisoptera sitting and holding on to a plant or bank structure or in flight. Only in one case was an Aeshna cyanea female caught by the frog's tongue. This was possible because the ovipositing female had just taken off from the stem, having lost hold and not yet being in forward flight. In contrast, $A$. imperator females, in forward flight, could escape, having enough kinetic energy to overcome the adhesive power of the tongue. Successful catches by the tongue were seen, especially when the tongue hit a wing. Dragonfly wings are covered by small spines, improving the aerodynamic characteristics of the wings (D'Andrea \& Carfi, 1988, 1989), but these spines are rough structures onto which a very pliable and sticky surface like that of a frog's tongue can adhere very well.

We found large differences in the success of frogs hunting Odonata. Zygoptera were caught more often than Anisoptera. This might be because Anisoptera can fly faster and more powerfully than Zygoptera (Rüppell, 1989). Flying Anisoptera have much more kinetic energy, good for detaching from the frog's tongue, than Zygoptera. Especially the large A. imperator escaped the frog, mostly by powerful wing beats, even underwater. Only when their body was struck or their wings were blocked by the frog's mouth were the dragonflies not able to escape.

Still, the hunt for A. imperator must be rewarding for frogs, because this large dragonfly is about 30-50 times heavier than small Zygoptera such as E. cyathigerum or C. puella, while the capture rate of Zygoptera was only 3-5 times higher than that of A. imperator.

Females were caught more often than males, corresponding to Corbet $(1999$, p. 34), because of their approach to the water's surface for egg-laying. Only in those species laying eggs in tandem, mostly above the surface, like $C$. puella, some males were eaten too, when the entire tandem pair was caught. This is in line with findings of several authors (Convey, 1992; Fincke, 1982; Waage, 1972). But, when flying alone, males of Calopteryx were more often caught in spider webs than females (Rehfeldt, 1992).

The capture rate between E. cyathigerum and C. puella differed, 35.3\% and 50\%, respectively. This may be explained due to the mode of egg-laying: E. cyathigerum females mostly oviposit submerged, while C. puella females lay eggs above the water. Egg laying in Zygoptera is often performed in tandem with guarding males in an upright position (termed the Agrion or sentinel position; Corbet, 1999, p. 29), providing predator protection (shown for C. puella, Rehfeldt, 1991) because the upright male commands a wide view.

Large differences exist between odonate species that oviposit in flight (exophytic) such as in the libellulids, and endophytic laying species like all the others investigated. Only in a few exophytic ovipositing tandem pairs of Sympetrum were frogs successful. The vast majority of captured odonates were endophytic ovipositing species. The amount of time needed to take off when ovipositing endophytically often seems to be too long to escape, especially when the holedrilling was in progress.

We also observed several attacks in male and female flying Anisoptera, but never observed a successful capture by a frog.

These results show that even in the sensitive period of oviposition most Odonata could escape jumping frogs with their very sophisticated hunting tactics, because of their outstanding flight manoeuvrability.

\section{Supplementary data}

Supplemental data for this article can be accessed here https://doi.org/10.1080/13887890.2020.1733328 


\section{Acknowledgements}

We are very thankful to Georg Seifert who cleaned the English of the first version, and two anonymous reviewers who provided very important comments. John Abbott helped to improve the final manuscript.

\section{References}

Anderson, C. W. (1993). The modulation of feeding behavior in response to prey type in the frog Rana pipiens. Journal of Experimental Biology, 179, 1-12. https://jeb.biologists.org/content/jexbio/179/1/1.full.pdf

Bomphrey, R. J., Nakata, T., Henningsson, P., \& Lin, H.-T. (2016). Flight of the dragonflies and damselflies. Philosophical Transactions of the Royal Society B, 371, 1704. http://doi.org/10.1098/rstb.2015.0389

Collett, T. S., \& Udin, S. B. (1988). Frogs use retinal elevation as a cue to distance. Journal of Comparative Physiology A, 163, 677-683. https://doi.org/10.1007/BF00603852

Conrad, K. F., \& Pritchard, G. (1992). An ecological classification of Odonate mating systems: the relative influence of natural, inter- and intra-sexual selection on males. Biological Journal of the Linnean Society, 45(3), 255-269. https://doi.org/10.1111/j.1095-8312.1992.tb00643.x

Convey, P. (1992). Predation risks associated with mating and oviposition for female Crocothemis erythrea (Brullé) (Anisoptera: Libellulidae). Odonatologica, 21(3), 343-350. http://natuurtijdschriften.n1/record/592000

Corbet, P. (1999). Odonata. Ecology and behaviour of dragonflies. New York: Harley Books.

Curley, E. A. M., Rowley, H. E., \& Speed, M. P. (2015). A field demonstration of the costs and benefits of group living to edible and defended prey. Biology letters: Animal Behaviour, 11(6), doi.org/10.1098/rsbl.2015.0152.

D'Andrea, M., \& Carfi, S. (1988). Spines on the wing veins in Odonata 1: Zygoptera. Odonatologica, 17, $313-335$. http://natuurtijdschriften.nl/record/591838

D'Andrea, M., \& Carfi, S. (1989). Spines on the wing veins in Odonata 2: Anisozygoptera and Anisoptera. Odonatologica, 18, 147-178. http://natuurtijdschriften.nl/record/591863

Dijkstra, K.-D. (2006). Dragonflies of Britain and Europe. Gillingham, UK: British Wildlife Publishing.

Ellington, C. P. (1984a). The aerodynamics of animal hovering flight. Philosophical Transactions of the Royal Society B, $305,1-181$.

Ellington, C. P. (1984b). The aerodynamics of flapping animal flight. American Zoologist, 24, 95-105.

Fincke, O. M. (1982). Lifetime mating success in a natural population of the damselfly, Enallagma hageni (Walsh) (Odonata: Coenagrionidae). Behavioral Ecology and Sociobiology, 10(4), 293-302. https://doi.org/10.1007/BF00 302820

Grabow, C., \& Rüppell, G. (2014). Wing loading in relation to size and flight characteristics of European Odonata. Odonatologica, 24(2), 175-186. https://doi.org/10.1007/BF00302820

Günther, R. (1996). Die Amphibien und Reptilien Deutschlands. Jena: Gustav Fischer Verlag.

Kleinteich, T., \& Gorb, S. N. (2015). Frog tongue acts as muscle-powered adhesive tape. Royal Society Open Science, 2, 150333. https://doi.org/10.1098/rsos.150333

Marsh, R. L., \& John-Alder, H. B. (1994). Jumping performance of hyalid frogs measured with high-speed cine film. Journal of Experimental Biology, 188, 131-141. https://jeb.biologists.org/content/jexbio/188/1/131.full.pdf

Nishikawa, K. C., \& Roth, G. (1991). The mechanism of tongue protraction during prey capture in the frog Discoglossus pictus. Journal of Experimental Biology, 159, 217-234. https://jeb.biologists.org/content/jexbio/159/1/217.full.pdf

Noel, A. C., Guo, Y. H., Mandica, M., \& Hu, D. L. (2017). Frogs use a viscoelastic tongue and non-Newtonian saliva to catch prey. Journal of The Royal Society Interface, 14, 127. http://doi.org/10.1098/rsif.2016.0764

Rehfeldt, G. E. (1990). Anti-predator strategies in oviposition site selection of Pyrrhosoma nymphula (Zygoptera: Odonata). Oecologica, 84, 233-237. https://doi.org/10.1007/BF00319406

Rehfeldt, G. E. (1991). The upright male position during oviposition as an anti-predator response in Coenagrion puella (Odonata: Coenagrionidae). Odonatologica, 20, 69-74. http://natuurtijdschriften.n1/record/591935

Rehfeldt, G. E. (1992). Impact of predation by spiders on a territorial damselfly (Odonata: Calopterygidae). Oecologica, 89, 550-556. https://doi.org/10.1007/BF00317162

Rehfeldt, G. E. (1995). Natürliche Feinde, Parasiten und Fortpflanzung von Libellen. Odonatological Monographs, 173 pp., Braunschweig.

Rüppell, G. (1984). Rana esculenta (Ranidae) Beuteerwerb. Publikation zu wissenschaftlichen Filmen, E 2819, IWF Göttingen, TIB Hannover.

Rüppell, G. (1989). Kinematic analysis of symmetrical flight manoeuvres of Odonata. Journal of Experimental Biology, 144, 13-42. https://jeb.biologists.org/content/jexbio/144/1/13.full.pdf

Rüppell, G., \& Hilfert-Rüppell, D. (2020). Rapid acceleration in Odonata flying: highly inclined and in-phase wing beating. International Journal of Odonatology, 23(1), 63-78. https://doi.org/10.1080/13887890.2019.1688017

Waage, J. K. (1972). Longevity and Mobility of Adult Calopteryx maculata (Beauvois) (Zygoptera: Calopterygidae). Odonatologica, 7, 77-88. http://natuurtijdschriften.nl/record/591243

Weis-Fogh, T. (1973). Quick estimates of flight fitness in hovering animals including novel mechanism for lift propulsion. Journal of Experimental Biology, 59, 169-230. https://jeb.biologists.org/content/jexbio/59/1/169.full.pdf 